\title{
Narrow pasts and futures: how frames of sustainability transformation limit societal change
}

\author{
Janina Priebe ${ }^{1,2}$ (D) Erland Mårald ${ }^{1}$ (D) $\cdot$ Annika Nordin $^{3}$ (D)
}

Accepted: 19 August 2020 / Published online: 5 September 2020

(C) The Author(s) 2020

\begin{abstract}
Two frames dominate present-day interpretations of sustainability and approaches to sustainability transformation in national and global policy arenas. One frame relates to transformation in global environmental governance that promotes goal-oriented agendas. The other frame relates to earth system sciences where sustainability transformation means breaking the devastating trends of the Anthropocene. In this paper, we examine the historical and cultural underpinnings of these two frames, each invoking particular relations and approaches to sustainability transformation. Our contribution is to discuss the role of the past in these frames and to illuminate how current outlooks toward the future still rely on principles that emerged in eighteenth- and nineteenth-century Europe and thus hinder alternative approaches to transformation in the present.
\end{abstract}

Keywords Sustainability $\cdot$ History $\cdot$ Sustainability transformation $\cdot$ Frame $\cdot$ Climate change $\cdot$ Agenda $2030 \cdot$ Sustainable development goals $\cdot$ Earth system sciences

\section{Introduction}

Calls for societal transformation toward sustainability have come from all levels of public and corporate policy-making in recent years. Non-governmental organizations as well as research suggest that climate and ecological crises require an unprecedented effort and societal change (Adloff and Neckel 2019; UN 2015). The IPCC special report released in October 2018, as a response to the United Nation's Paris Agreement signed in 2016, pointed out that limiting global warming to 1.5 degrees Celsius above pre-industrial levels and ensuring

Janina Priebe

janina.priebe@umu.se

Erland Mårald

erland.marald@umu.se

Annika Nordin

annika.nordin@slu.se

1 Department of Historical, Philosophical and Religious Studies, Umeå University, Umeå, Sweden

2 Arctic Research Centre, Umeå University, Umeå, Sweden

3 Department of Forest Genetics and Plant Physiology, Swedish University of Agricultural Sciences, Umeå, Sweden the functioning of ecosystems and human health would require "rapid and far-reaching transitions in land, energy, industry, buildings, transport and cities" (IPCC 2018).

The vision of sustainability transformation, a profound and fundamental change in how society relates to nature, is seen as the only possible way out of the downward spiral. The future pathways shaped in the current discourse, however, run the risk of limiting actual transformation because they either lack legitimacy, reduce the diversity of actors and knowledge types, or represent business-as-usual approaches (Blythe et al. 2018; Colocousis et al. 2017).

Two frames in particular dominate present-day interpretations of sustainability and approaches to initiating sustainability transformation. One frame relates to transformation in global environmental governance that promotes goaloriented agendas. The other frame for sustainability transformation relates to earth system sciences, where sustainability transformation means breaking the devastating trends of the Anthropocene.

Overall, the ambiguities and limitations of these two frames as well as the tensions between them are well explored. We also recognise earlier research on the emergence of the concept of sustainability in environmental policies in the second half of the twentieth century and the critique of the ambivalent notion of sustainable development (Caradonna 2014; Robinson 2004). What is missing from these discussions, 
however, is an examination of the historical and cultural underpinnings of the dominating frames that fail to deliver real change toward sustainability.

The debate about transformation is strongly oriented toward the future, whereas perceptions of the past and the ways these enable or impede change are barely considered. Yet, the understandings of the past, though oblique, are reflected in the metaphors and imagery as well as in the logic of the promoted approach to climate change and ecological crises. To expound upon these understandings of the past, we examine what role is assigned to the past and how historical developments are interpreted and used to argue for change in the present in the prevailing frames of sustainability transformation. By analysing how meaning is given to particular approaches to sustainability transformation, our contribution is to critically discuss the central but problematic role of the past in these frames.

\section{Framing sustainability transformation}

The notion of sustainability transformation has spawned a whole research field (e.g. Clark and Harley 2019; Linnér and Wibeck 2019), and it has replaced the much-debated concept of sustainable development with "transformation" as the leading principle of policies on the local, national, and global level.

The language of the current sustainability discourse is saturated with metaphors of great leaps and humankind's transforming power, thereby activating certain frames of interpretation and action. As we will elaborate on in this paper, we find that references to two frames clearly dominate approaches to sustainability transformation. The term "transformation" itself activates frames relating to human industriousness and the ability to shape both society and environment alike.

The cognitive linguist George Lakoff defines frames as the conceptual structures that link language to meaning (Lakoff 2010). The frames are part of a system of individual human perceptions, which functions as a framework for interpretations (Lakoff 2010; Goffman 1974). Lakoff focusses on how expressions, and the narratives that are evoked within particular frames, activate (or block) strategies for change in people's behaviour. We are aware that researchers have criticized, among other aspects, Lakoff's role as a climate change and environmental communications expert with a publicly progressive stance (e.g. Brulle 2010).

As the purpose of this paper is to trace assumptions about the past in frames that shape the currently prevailing discursive frames of sustainability transformation, Lakoff's theory needs to be connected to a wider understanding of frames, especially in cases where scientific knowledge is integrated into frames and leads to different responses (Pinker and Lakoff 2007). In our analysis, we thus relate insights from the understanding of linguistic frames to frames as they are understood in the social sciences. The latter uses the concept of frame to illuminate interpretative practice, and actors' perceptions about reality, as well as what ways of communicating about and organising society this entails, for instance, regarding climate change responses (Blue 2016).

In brief, the two frames that this article highlights and that are repeatedly activated in the present-day debate about sustainability transformation can be delineated as follows. The frame of global environmental governance consists, among others, of the roles of global institutions and nation states. Relations considered meaningful within this frame are, for instance, the global institutions, such as the United Nations (UN), that provide agendas for coordinated action to be implemented by the states, which in turn hand down this agenda to regions and municipalities. Sustainability transformation is framed as the reward for successful progress through the agenda for sustainable development (UN 2015) that ensures a way to stay "on track" toward predetermined goals. This frame delineates clearly how sustainability transformation can be initiated. It confines action to actors connected on a global level, and determines action as being directed from the top level. Besides the UN member states, the UN also consists of the so-called third UN, which includes experts, private economy actors, and large non-governmental institutions that are globally connected (Koehler 2015). The latter actors have acquired meaningful roles in the frame of global environmental governance, and they are presented to have key positions for sustainability transformation. In contrast, citizens and issue alliances, or unexpected and uncoordinated behaviour, are not part of this frame, despite their growing importance for climate action in practice (MacLean 2020).

The second frame we critically explore is that of earth systems sciences, which includes the roles of natural scientists, governmental bodies, and the Earth's natural systems. In the twentieth century, earth system sciences brought together natural sciences about planetary processes, like hydrology, climatology, and geology, with social sciences that engaged with processes seen to function on a global level, too, such as economics and population dynamics. The perspective of earth system sciences was born out of the increased computational capacity to process large amounts of quantitative data, and it encouraged the interpretation of changes according to those trends that became identifiable (Robin et al. 2018).

The earth systems perspective emphasises inertia and longterm statistical trends with devastating effects (Bretherton 1985). By digging down in ice cores and sediment layers, earth systems science uncovers rhythms and aberrations over millions of years of past trajectories (Jouzel et al. 2007; Zachos et al. 2001). This frame assigns key roles to longitudinal graphs concerning, for instance, populations, energy use, transportation, carbon dioxide, methane, ocean acidification, tropical forest loss, and terrestrial biosphere degradation that 
should act as motivators for change (Hampton et al. 2013; Steffen et al. 2015). The earth systems sciences' framing of sustainability transformation focuses on turning around trends of, for instance, particle concentrations, but does not demand a questioning of societal structures or agency, or the practices driving the identified trends.

\section{Understandings of transformations in history}

The term "sustainability transformation" in national and global policy arenas reflect the principles and values defined during the European industrialisation and relating to, broadly speaking, keeping up the material basis of industrial development. In recent transformations literature, too, the role of indigenous and placed-based knowledge is marginalized, and, if examined, focusses mainly on regions historically considered remote from centres of industrial development, such as the Arctic (Lam et al. 2020). As a result of this lack of diversity, calls for alternative approaches to sustainability transformation have grown over the past decades, including the acknowledgement of different types of knowledge and cultural contexts (Brown et al. 2013; Ives et al. 2020), and the focus on local instead of global perspectives (Balvanera et al. 2017). However, the understanding of sustainability transformation in global institutions and economic system is firmly rooted in the Western scientific paradigm, and it still resonates with the notion of sustainable development that has prevailed since the second half of the twentieth century.

Throughout human history, different understandings and interpretations of profound societal change have laid the foundations for different approaches to inform, guide, and facilitate transformation, or to maintain business as usual and prevailing power structures. These understandings have always been formed in a specific context, and they have reflected people's hopes as much as they have mirrored fears, and this repertoire of interpretations continues to define our approaches to sustainability transformation.

One long-standing approach to societal change is the notion of human societies striving toward a telos - a destiny or a state of completion - like the realisation of liberalism or modernity. Forged in continental Europe, this teleological thinking has inspired different interpretations of the past and the future to very different ends. The belief in the progress of human society toward the better was, however, always at the centre of this way of thinking (Scott 1998). This has been a well-known historiographical outlook since the eighteenth century, and it provided the philosophical underpinning of industrialisation. German philosopher Georg W. F. Hegel (1770-1831) understood the ideals of European civilisation as possessing a formative power, moving through history from East to West, where Hegel believed it reached its completion (Friese 2010; Lumsden 2018). The German philosopher and legal scholar Karl Marx (1818-1883) saw the past, the present, and the future as being driven by the prevailing mode of production, thereby forging social classes, ideologies, and ways of thinking (Marx 1867). Material conditions, economic relations, power struggles, and drastic transformations are thus at the core of this philosophy of history, where socialism finalises societal progress.

Although with a very different political-ideological backdrop, a similar teleological perspective, liberalism, was a shaping force in the first half of the twentieth century. The British historian Herbert Butterfield (1900-1979) criticized the retrospect interpretation of societal development as progress toward liberal democracy in his "Whig interpretation of history" (1931). The retrospect construction of progress, Butterfield concluded, neglected the perspectives of contemporaries on the changes of their own time and their options for change. The view on history as development along the lines of progress, however, became popular once again with the end of the Cold War. With the seeming victory of liberal democracy, the American political scientist Francis Fukuyama declared "the end of history" (Fukuyama 1992).

Another strand of thinking interpreted societal change as being an adjustment to inevitable circumstances that could not be influenced by societies. The French historian Braudel (1902-1985) developed the concept of la longue durée, the long duration, that connects historical events into societal and geological changes over millennia (Braudel 1982). The other two timespans identified by Braudel are the short-term événements, focussing on specific individuals and events, and the medium-term conjunctures, describing societal shifts over decades and centuries. It is, according to Braudel, the long duration that has the ultimate explanatory power, and this view has dominated the natural sciences since the late eighteenth century. The major interests of natural scientists revolved around how long, drawn-out geological changes shaped the basis for the diversity of life, as explained, for instance, in Charles Darwin's theory of biological evolution (Bowler 1992; Toulmin and Goodfield 1982).

The British cleric and political scholar Thomas Robert Malthus (1766-1834) provides another prominent example for seeing explanatory power in the long-term trends of history. At the turn of the nineteenth century, Malthus derived from the observation of past developments that population growth was exponential, while food supply growth was linear-a condition that inevitably pointed at a coming collapse (Malthus 1798). This way of connecting the past and the future became prevalent in social planning and future studies during the second half of the twentieth century (Andersson 2018). These understandings of how profound change in society takes place and can be brought about merged into the underpinnings of sustainability transformation. 


\section{Underpinning the frames of sustainability transformation}

Warnings of environmental and societal decline were frequent in the nineteenth century, with the fall of the Roman Empire as the prime example (Gibbon 1776-1789; Diamond 2005). The narrative of how environment and society are bound to each other if one tumbles toward the abyss is the origin of the idea of sustainability (Warde 2018). The concept of sustainability itself, meaning the keeping human endeavours within the limit of nature's resources and replenishment rates, originated from German scientific forestry's idea of Nachhaltigkeit in the mideighteenth century. The idea of sustainable yield was about keeping timber extraction and forest growth in balance because the shortage of wood would massively impede industrial development (Caradonna 2014). The concept of sustainability more broadly was further triggered by the observation of nature's degradation in the wake of industrialisation in Europe.

The notion of "paradise lost", nature's decline at the hands of humans, has over the years seen different underlying narratives where Christianity (White 1967), science (Merchant 1981), or capitalism (Moore 2017) were seen as the culprits that have compromised the ecological foundation and pristineness of our world. Similar narratives have laid the foundation for environmentalism since the 1960s and 1970s, but they have a much longer history in, for instance, the European and American nature conservation movements in the nineteenth century that followed diverse objectives (Warde et al. 2018).

Ensuring that nature would continue to provide for industrial growth and development was again at the centre of the sustainable development discourse during the second half of the twentieth century, while other objectives of sustainability were sidetracked and contained in the sphere of non-governmental actors and environmental interest groups (Robinson 2004). This frame is an antidote to the declensionist narratives described above (McNeill 2003; Melosi 2010). Paradoxically, though, especially the understanding of sustainability transformation in the arena of environmental governance also feeds on narratives of decline that conjure up the approaching catastrophe if current rates of consumption, greenhouse gas emissions, and acidification are not radically cut.

The aim of environmental governance is to set up an agenda that gets society off of the downward spiral of unsustainable practices. In 1992, the United Nations' Earth Summit resulted in the establishment of Agenda 21, the first clearly goal-oriented global environmental strategy and the predecessor to both the Millennium (2000) and Sustainable Development Goals (2015). Finalising and uniting progress on all levels of development in society, economy, and the environment within a manageable timeframe of a few years or decades became the guiding idea of global environmental governance and was handed down to national and local policy arenas.

We can easily recognise that seeing the future as an agenda we set up firmly relates to a teleological understanding of history and future that was a known understanding of change throughout history (Sardar 1993). In the case of global environmental governance, however, this approach entails maintaining an idea of progress that emerged during industrialisation-a historical period that is now deemed to be the origin of unsustainable structures, practices, and habits in society and economics. The language of goals, development, and progress manifests in a frame that leads to envisioning sustainability transformation as the continuing progress of society along the known path of development.

Moreover, while adopting the language of organisation and management realms, both corporate and public actors increasingly approach the transformation toward sustainability as a "business case" or "strategy", meaning the alignment of actions to reach a specific goal (e.g. Epstein and Rejc Buhovac 2010). In corporate sustainability strategies, however, the process to attain the goal of sustainability is commonly subordinated to previously prioritised ends and embedded in existing structures (Landrum and Ohsowski 2018).

Research, too, has turned to engage with "sustainability challenges" and "problem-solving". Tapping new sources of knowledge, for instance, through engaging with stakeholders in transdisciplinary projects or developing tools to enhance problem-solving creativity, are focus areas of these recent approaches to "tackle" or "solve" sustainability problems (Carlsson et al. 2015; Klenk and Meehan 2015; Polk 2014).

Considering the historical understandings of societal change, there is another facet of how sustainability transformation is approached. Earth systems science is a key to interpreting environmental changes, which are increasingly translated into what should be done in society to accommodate these changes. The past appears as the origins of trends, anchoring the approach to sustainability transformation in a large-scale temporal and spatial perspective.

Following the Malthusian idea of exponentially increasing threats, the Club of Rome, a group of world-leading economists and scientists, published the report "The Limits to Growth" (1971). The publication of the report led to intense debate in the 1970s when it used computer models to put the limelight on the critical line between human growth and the planet's carrying capacity. The report applied the Malthusian conception of the past (Meadows et al. 1972). Only shortly after, the idea of ecological overshoot, the crossing of the limits of earth's carrying capacity to support the human population, developed on the same grounds (Catton 1982). The notion of long-term statistical trends that could extend from the past into a catastrophic future remained at the centre of the sustainability discourse during the late twentieth century. This understanding of history laid the groundwork for defining 
sustainability as the effort to stay within planetary limits and to handle the scarcity of resources (Bushel et al. 2015).

With the conception of the past as the origin of long-term trends, future developments are derived from historical data, leading to the identification of irreversible developments and tipping points based on past conditions. Visually, the data take on the shape of a sharply rising curve, be it population growth or parameters of ecological decline, pointing at the coming collapse. In recent years, the image of the curve's sharp rise from the 1950s onward has become known as the "hockey stick", continuing its climb into the future as human impacts on ecological systems increase even more (Mann 2013).

This salient visualisation of trends and tipping points indicates an emergency and the need for an urgent response (Russill and Nyssa 2009). Researchers claim that the pace of human impact on the ecological systems on a planetary scale has in recent times taken up speed - a shift referred to as the Great Acceleration (McNeill and Engelke 2014; Steffen et al. 2015). The Great Acceleration can be understood as the intensifying phase of the Anthropocene, the geological period marking the significant impacts of human activities and specific economic structures on global ecosystems and geology (Subcommission on Quaternary Stratigraphy 2015; Lewis and Maslin 2015).

\section{One-dimensional outlooks_failing transformation}

Environmental governance and earth systems sciences have built up frames that create one-dimensional outlooks on the future. Imagining trend lines that extend from the past into the future, as it is evoked by the earth systems science frame, is the creation of meaning by selecting parameters to be measured as proxies for substantial societal changes. For example, the measurement of greenhouse gases and the impact assessment of industrial pollution on the earth's climate undoubtedly deal with reality, regardless of the perspective on the consequences or implications for actions.

Combining trend lines also means interpreting correlations between different parameters as causal relations and establishing axiomatic agendas as a result. The UN Paris Agreement (2016) and the UN 2030 agenda (2015) both emphasise the link between $\mathrm{CO}_{2}$ emissions and historical economic development of the industrial states. This direct link was true for the past, and still today, the narrative established by these trends, combining the rising $\mathrm{CO}_{2}$ curve with growing economic wealth, implies the idea that a reduction of the former inevitably leads to a reduction of the latter. This conclusion, in turn, weakens ways of thinking of economic development as being decoupled and independent from emissions (Kallis 2018). Donald Trump, the president of the USA, announced in June 2017 that the USA had withdrawn from the Paris Agreement in which the signing member states committed to reducing their greenhouse gas emissions in order to limit the global average temperature rise to below 2 degrees Celsius above pre-industrial levels. The argument was based on the assumption that limiting emissions would weaken economic development in the USA, using the link established between the past long-term trends of economic development and $\mathrm{CO}_{2}$ emissions as the prime argument (Tollefson 2017). This argument resembles what has since the late nineteenth century been understood as the link between energy consumption and societal advancements, brought forward by the British intellectual Herbert Spencer. Still, and despite the models offering alternative views on production and consumption, the thesis of energy flow that translates into societal development has remained a powerful frame throughout the twentieth century until to date (Rosa et al. 1988).

In the same way, the critique that accompanied the "Limits to Growth" report targeted the linking of long-term trends. The report's major flaw did not lay in the prediction of population growth itself, critics pointed out, but in the assumed direct correlation between the earth's carrying capacity and land area, and the focus on physical instead of societal factors (Cole 1999). Rather than as the only conceivable correlation, these critiques suggested that the relation should be regarded as just one of many possible interpretations where two different developmentspopulation growth and land use - are directly and causally linked. The choice of relations between parameters to identify "trends" establishes explanations and connections, and these, in turn, can manifest in values that are difficult to change and that inhibit radical new ways of thinking.

Today, too, the two prevailing frames of sustainability transformation offer only limited types of actions that are promoted as suitable and effective answers to imagined pasts and futures. The actions that are represented as being central are, on the one hand, the aversion of catastrophe, and, on the other hand, following the predetermined roadmap toward sustainability. In the frame of earth systems science, the curves that visualise the global-scale impacts of industrial activities since the Great Acceleration take on the role of early warning signs or act as clear evidence that planetary boundaries of humanity's safe operating space have already been crossed (Dryzek and Pickering 2019; Rockström et al. 2009; Schneider 2014). The metaphor of the tipping point, visualised by the abruptly rising curves in climate and environmental service data, lets us imagine we are standing at the abyss (Karlsson 2016). From here departs the idea of the climate crisis as an "imminent peril", and to ensure sustainability and avert catastrophe actions beyond what societies have established as acceptable decision-making processes are silently accepted (Lakoff 2007; Markusson et al. 2014).

The earth system science frame with its focus on long-term trends creates a stark ambivalence between the perceived urgency to act and the ineffectiveness of the actions initiated in this frame (Strunz et al. 2019). Trend thinking fuels emergency rhetoric, while implying that local actions in the present are ineffective because the dangerous trend of climate change began long 
ago and has already reached a scale beyond individual or community control.

Understanding the past as the origin of trend lines emphasises inertia by highlighting the evolutionary buildup, or the gradual and inexorable decline (or progress) of structures, institutions, and regimes (Bijker et al. 1989; Geels 2002; Mahoney 2000). This frame manifests the lock-ins and gridlocks societies have struggled with since the onset of the overwhelming unsustainable trends, and it even inhibits transformative changes that could end the conflicts and deficiencies originating in the past (Liebowitz and Margolis 1995; Matutinovic 2007). One example of how permanent the frames for thinking and the promoted combination of trend lines and values into fixed agendas can become comes from late nineteenth century Britain and the early-industrial town of Manchester. The environmental historian Stephen Mosely identifies the "correlation between pollution and prosperity" where coal smoke in the house and the city was seen to indicate the wealth and well-being of its inhabitants (Mosley 2001). Initiatives to promote other types of energy, coming from different business and NGO backgrounds, used human health, environmental pollution, and urban aesthetics as main arguments to support a narrative that linked coal smoke to inefficiency and waste. These arguments did not, Mosley concludes, diminish the coal smoke's appeal as a familiar indicator of wealth at that point. Coal smoke and the pollution resulting from it were already part of another, more compelling narrative that connected the coal hearth and smoke-blackened surfaces and walls in homes with both prosperity and the agency to choose their "goals in life" (Mosley 2001, 116).

A similar dynamic is observable in the ongoing energy transition in the twenty-first century, and "petrocultures" have recently come into focus in research. During the last century, fossil oil, and the products made from it, has shaped our societies' identities to a considerable extent, giving way to a "petroculture". Fossil oil has connected us to global commercial networks, transformed the material world around us, altered our bodies, and formed our understandings with seemingly infinite progress and global mobility (Wilson et al. 2017). The term "petromelancholia" has been suggested to describe the grieving of oil resources and the pleasures they sustain (LeMenager 2013). At its heart lies the same close association of wealth and environmental pollution that Mosely identified for smoke-blackened walls and furniture. The examples of petromelancholia and late nineteenth century Manchester's coal smoke show how the dimensions of history and future are attached to the present, continually affecting our understandings, deliberations, and decision-making.

\section{Why do both frames fail to initiate transformative change?}

In this paper, we use the concept of frames to analyse, in particular, the role of the past in current frames of sustainability transformation. Understandings of the past, we argue, are crucial for what options are considered to be viable to initiate transformative change. The present-day debate is dominated by just two frames that diminish alternative understandings and narratives, thereby offering only limited creativity and innovation for change. The last decades have also seen a streamlining of responses to climate change and ecological crises with the institutionalisation of environmentalism (Robin et al. 2018). The frames of environmental governance and earth systems science both rely on simplified imaginary and language, illustrated by the hockey stick curves and the colourful seventeen boxes containing the Sustainable Development Goals.

Most crucially, however, the roots of these future outlooks build on the proposition of interconnected industrial and societal development that came to be widely accepted in the eighteenth and nineteenth century Europe. Today, it remains axiomatic that societal development relates to satisfying the needs of an industrialised society, still manifesting imagined connections between progress, economic growth, emissions, natural resource extraction, and wealth. These understandings exclude alternative notions of what sustainability transformation can entail, and they stalemate attempts to overcome worn out ideas.

The systems that are activated by references to environmental governance and earth systems science frames do not provide any useful tools or reactions to initiate sustainability transformation in the context of present-day society. Instead, these frames create feelings of insufficiency and "climate angst", or fatalism and denial (Norgaard 2011). We see a focus on either catastrophic tipping points or the management of off-track challenges. Figure 1 shows how the past is used as a basis for how future challenges are interpreted and how these interpretations, for instance, seeing either tipping points or offtrack challenges, lead to a certain framing of solutions.

The repertoire of understandings of and approaches to transformative change seems to oscillate between limitations and boundlessness. The historical roots of sustainability, closely linked to increasing uses of renewable natural resources, centred on identifying the limits of sustainable yield of a resource's extraction level. The 1970s saw an acute awareness of limits, and a renewed critique of economic and population growth, spurred by the oil crisis and environmental justice movements sending ripples through the global system. However, the discourse turned, within years, to revolve around the formula that would create a "win-win" scenario, and the balance of social, economic, and environmental sustainability as a save way to continue on the growth pathway (Purvis et al. 2019). A further reduction of the facets of sustainability occurred with the substitution of "sustainable" with "green" practices and products, which further narrowed the focus to individuals as consumers in the sustainability discourse of the last decade and distracted from systemic failures to ensure sustainability (Yanarella et al. 2009). The latest semantic turn toward "transformation" does not necessarily 


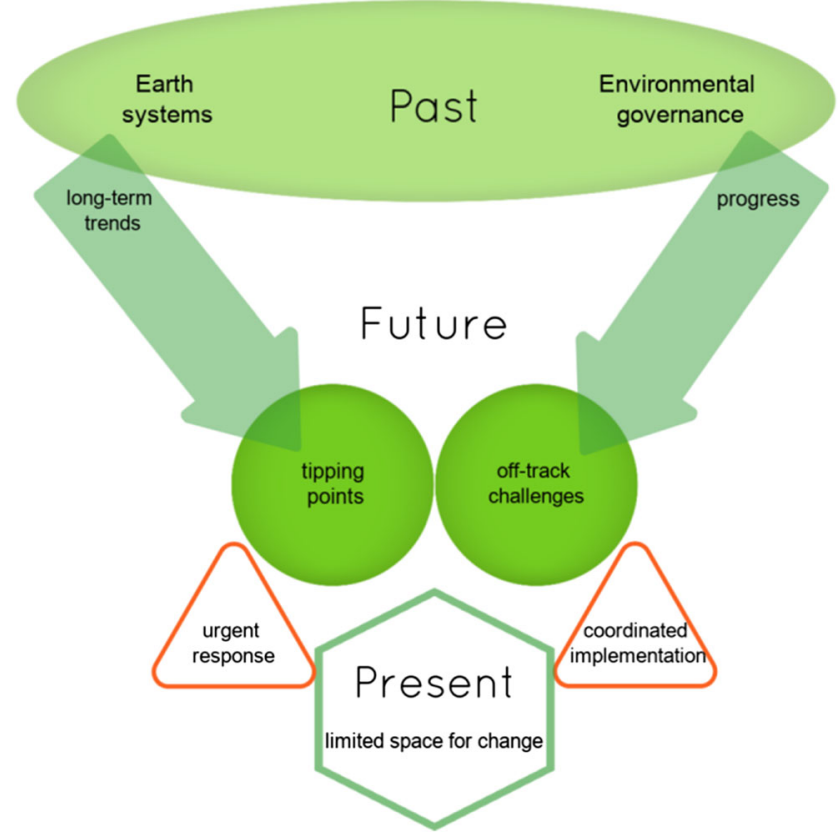

Fig. 1 This figure shows the prevailing references to the past in the two prevailing frames of sustainability transformation, and which kind of solutions these understandings entail; own figure in reference to Steffen et al. (2015) and the UN Sustainable Development Goals (UN 2015)

imply new ways of thinking, tools, and approaches either, contrary to its appearance (Moretti and Pestre 2015). The roots of this problem, as we have shown in this paper, lie in the role that is assigned to the past.

Facing a lack of public response and effective political action to handle the urgent situation, attention is drawn to global-scale solutions like geoengineering for industrial carbon capture and solar radiation management (Markusson et al. 2014; Victor et al. 2009). These solutions, however, premise eco-authoritarian governance and preclude democratic processes (Shahar 2015; Shearman and Smith 2007; Ophuls 1977; Wigley 2006). The favouring of top-down solutions has resulted in a strand of denialism regarding the science of climate change that presents itself as a defender of liberal and democratic rights (Mann and Wainwright 2018).

Moreover, both frames disconnect options for transformative change from the here and now (Jamieson 2014; Morton 2013) and fail to motivate and legitimise sustainability transformation because it is "out of sync with the timelines experienced by and meaningful to people" (Lynch and Veland 2018, 83). They also promote sustainability solutions defined and steered through top-down processes. The neglect of social and local dimensions illustrates how the current discourse struggles to provide new views on present-day social structures and how it leaves aside questions about transforming structures of finance and economy that have, to a great extent, led to the sustainability crises societies face today (HorceaMilcu et al. 2019; Markard et al. 2012; Stirling 2014; Scoones et al. 2015).

\section{Concluding remarks}

Our current understanding of the past can turn sustainability transformation into either an authoritarian nightmare or an unachievable dream. In the time of global climate change and ecological crises, it is often argued that we can only look toward the future because all points of reference established in the past are void in the face of the unprecedented challenges to humanity in the twenty-first century, leaving us with no helpful experience to fall back on in the face of an uncertain and threatening future (Beck 2004; Giddens 2003; McNeill 2001). The frames that are activated in the current discourse on sustainability transformation lead us to believe that our agency in the present is reduced to quick responses that override democratic, deliberative, and local options in order to avoid tipping points.

Today, it is not a lack of knowledge or technical solutions that inhibits societal transformation. Instead, studies in sustainability science frequently point out that current attempts to advise, guide, and implement sustainability suffer from an inability to examine and challenge prevailing values, habits, and ways of thinking (Cornell et al. 2010; Dryzek and Pickering 2019; Horcea-Milcu et al. 2019; Stirling 2014). This resonates with ideas that our society at the "end of history" (Fukuyama 1992), being stuck in an eternal now, cannot imagine a future that radically differs from the present (Hartog 2015).

We may, however, break free from the "eternal now" by finding new points of reference for what is thinkable and doable in the here and now. Researchers, too, can create space for different versions of societal change through an empowering and liberating view on the past, the future, and the present (Fazey et al. 2018; Harvey 1996). By questioning what we have been taking for granted in our perspectives on the past and the future, we can identify the transformative potential that lies in the present, allowing us to create space for sustainability transformation that rests on responsibility and accountability on all levels of action.

Acknowledgements Open access funding provided by Umea University. We thank our colleagues in the project Anna Sténs, Elsa Reimerson, Camilla Sandström, Eva-Maria Nordström, Isabella Hallberg-Sramek, and Annika Mossing. We also want to thank Daniel Nyström for giving constructive comments on the manuscript.

Funding This research was funded through the interdisciplinary research project "Bring down the Sky to the Earth: How to use forests to open up for constructive climate change pathways in local contexts" supported by FORMAS, the Swedish Research Council for Sustainable Development (dnr. 2017-01956).

Open Access This article is licensed under a Creative Commons Attribution 4.0 International License, which permits use, sharing, adaptation, distribution and reproduction in any medium or format, as long as you give appropriate credit to the original author(s) and the source, provide a link to the Creative Commons licence, and indicate if changes were made. The images or other third party material in this article are included in the article's Creative Commons licence, unless indicated otherwise in a credit line to the material. If material is not included in the article's Creative Commons licence and your intended use is not permitted by 
statutory regulation or exceeds the permitted use, you will need to obtain permission directly from the copyright holder. To view a copy of this licence, visit http://creativecommons.org/licenses/by/4.0/.

\section{References}

Adloff F, Neckel S (2019) Futures of sustainability as modernization, transformation, and control: a conceptual framework. Sustain Sci 14:1015-1025. https://doi.org/10.1007/s11625-019-00671-2

Andersson J(2018) The future of the world: futurology, futurists, and the struggle for the post Cold War imagination. Oxford University Press, Oxford

Balvanera P, Calderón-Contreras R, Castro AJ, Felipe-Lucia MR, Geijzendorffer IR, Jacobs S, Martín-López B, Arbieu U, Speranza CI, Locatelli B, Harguindeguy NP, Mercado IR, Spierenburg MJ, Vallet A, Lynes L, Gillson L (2017) Interconnected place-based social-ecological research can inform global sustainability. Curr Opin Environ Sustain 29:1-7

Beck U (2004) A critical introduction to risk society. Pluto Press, London

Bijker WE, Hughes TP, Pinch TJ (eds) (1989) The social construction of technological systems: new directions in the sociology and history of technology. MIT Press, Cambridge

Blue G (2016) Framing climate change for public deliberation: what role for interpretative social sciences and humanities? J Environ Policy Plan 18:67-84

Blythe J, Silver J, Evans J, Armitage D, Bennett NJ, Moore ML et al (2018) The dark side of transformation: latent risks in contemporary sustainability discourse. Antipode 50:1206-1223

Bowler PJ (1992) The Fontana history of the environmental sciences. Fontana Press, London

Braudel F (1982) On history. University of Chicago Press, Chicago

Bretherton FP (1985) Earth system science and remote sensing. Proc IEEE 73:1118-1127

Brown K, O’Neill S, and Fabricius C (2013) Social science understandings of transformation. Pages 100-107 in ISSC and UNESCO. World Social Science Report (Changing Global Environments) 2013

Brulle RJ (2010) From environmental campaigns to advancing the public dialog: environmental communication for civic engagement. Environ Commun 4(1):82-98

Bushel S, Colley T, Workman M (2015) A unified narrative for climate change. Nat Clim Chang 5:971-973

Caradonna JL (2014) Sustainability. A History. Oxford University Press, Oxford

Carlsson A, Hjelm O, Baas L, Eklund M, Krook J, Lindahl M, Sakao T (2015) Sustainability jam sessions for vision creation and problem solving. J Clean Prod 98:29-35

Catton WR (1982) Overshoot. The ecological basis of revolutionary change. University of Illinois Press, Chicago

Clark WC, Harley AG (2019) Sustainability science: towards a synthesis. (No. 2019-01; sustainability science program working paper). John F. Kennedy School of Government, Harvard University

Cole MA (1999) Limits to growth, sustainable development and environmental Kuznets curves: an examination of the environmental impact of economic development. Sustain Dev 7(2):87-97

Colocousis CR, Rebellon CJ, Smith N, Sobolowski S (2017) How long can we keep doing this? Sustainability as a strictly temporal concept. J Environ Stud Sci 7:274-287

Cornell S, Sörlin S, Costanza R, van der Leeuw S (2010) Developing a systematic science of the past to create our future. Glob Environ Chang 20:423-425

Diamond J (2005) Collapse: how societies choose to fail or succeed. Penguin, London

Dryzek JS, Pickering J (2019) The politics of the Anthropocene. Oxford University Press, Oxford
Epstein MJ, Rejc Buhovac A (2010) Solving the sustainability implementation challenge. Organ Dyn 39:306-315

Fazey I, Moug P, Allen S, Beckmann K, Blackwood D, Bonaventura M, Burnett $\mathrm{K}$ et al (2018) Transformation in a changing climate: a research agenda. Clim Dev 10:197-217

Friese H (2010) Times, histories and discourse. Rethink Hist 14:405-420

Fukuyama F (1992) The end of history and the last man. Simon and Schuster, New York

Geels FW (2002) Technological transitions as evolutionary reconfiguration processes: a multi-level perspective and a case study. Res Policy 31:1257-1274

Gibbon E (1776-1789) The history of the decline and fall of the Roman Empire. Strahan and Gadell, London

Giddens A (2003) Runaway world: how globalization is reshaping our lives. Routledge, New York

Goffman E (1974) Frame analysis. Harper, New York

Hampton SE, Strasser CA, Tewksbury JJ, Gram WK, Budden AE, Batcheller AL, Duke CS, Porter JH (2013) Big data and the future of ecology. Front Ecol Environ 11:156-162

Hartog F (2015) Regimes of historicity. Presentism and experiences of time (S. Brown, trans.). Columbia University Press, New York

Harvey D (1996) Justice, nature and the geography of difference. Blackwell, Oxford

Horcea-Milcu AI, Abson DJ, Apetrei CI, Duse IA, Freeth R, Riechers M, Lam DPM, Dorninger C, Lang DJ (2019) Values in transformational sustainability science: four perspectives for change. Sustain Sci 14:1425-1437. https://doi.org/10.1007/s11625-019-00656-1

IPCC (The International Panel on Climate Change) (2018) Summary for Policymakers of IPCC Special Report on Global Warming of $1.5 \mathrm{C}$ approved by governments. https://www.ipcc.ch/2018/10/08/ summary-for-policymakers-of-ipcc-special-report-on-globalwarming-of-1-5c-approved-by-governments/ accessed July 72020

Ives CD, Freeth R, Fischer J (2020) Inside-out sustainability: the neglect of inner worlds. Ambio 49(1):208-217

Jamieson D (2014) Reason in a dark time. Why the struggle against climate change failed - and what it means for our future. Oxford University Press, Oxford

Jouzel J, Masson-Delmotte V, Cattani O, Dreyfus G, Falourd S, Hoffmann G, Minster B, Nouet J, Barnola JM, Chappellaz J, Fischer H, Gallet JC, Johnsen S, Leuenberger M, Loulergue L, Luethi D, Oerter H, Parrenin F, Raisbeck G, Raynaud D, Schilt A, Schwander J, Selmo E, Souchez R, Spahni R, Stauffer B, Steffensen JP, Stenni B, Stocker TF, Tison JL, Werner M, Wolff EW (2007) Orbital and millennial antarctic climate variability over the past 800 , 000 years. Science 317:793-796

Kallis G (2018) Degrowth. Agenda Publishing, Newcastle upon Tyne

Karlsson R (2016) Three metaphors for sustainability in the Anthropocene. The Anthropocene Review 3(2):23-32. https://doi. org/10.1177/2053019615599415

Klenk N, Meehan K (2015) Climate change and transdisciplinary science: problematizing the integration imperative. Environ Sci Pol 54:160-167

Koehler G (2015) Seven decades of "development", and now what? J Int Dev 27:733-751

Lakoff A (2007) Preparing for the next emergency? Publ Cult 19:247-271

Lakoff G (2010) Why it matters how we frame the environment. Environ Commun 4(1):70-81

Lam DPM, Hinz E, Lang DJ, Tengö M, von Wehrden H, Martín-López B (2020) Indigenous and local knowledge in sustainability transformations research: a literature review. Ecol Soc 25(1):3

Landrum NE, Ohsowski B (2018) Identifying worldviews on corporate sustainability: a content analysis of corporate sustainability reports. Bus Strategy Environ 27:128-151

LeMenager S (2013) Living oil: petroleum culture in the American century. Oxford University Press, Oxford

Lewis SL, Maslin MA (2015) Defining the Anthropocene. Nature 519(7542):171-180 
Liebowitz SJ, Margolis SE (1995) Path dependence, lock-in, and history. Journal of Law, Economics and Organization, pp 205-226

Linnér BO, Wibeck V (2019) Sustainability transformations. Agents and drivers across societies. Cambridge University Press, Cambridge

Lumsden S (2018) Hegel and pathologized modernity, or the end of spirit in the anthropocene. Hist Theory 57:371-389

Lynch AH, Veland S (2018) Urgency in the Anthropocene. MIT Press, Cambridge

MacLean J (2020) Rethinking the role of nonstate actors in international climate governance. Loy U Chi Int'l L Rev 16:21-43

Mahoney J (2000) Path dependence in historical sociology. Theory Soc 29:507-548

Malthus TR (1798) An essay on the principle of population. Reprint 2004. Edited with an introduction and notes by Geoffrey Gilbert. Oxford University Press, Oxford

Mann ME (2013) The hockey stick and the climate wars: dispatches from the front lines. Columbia University Press, New York

Mann G, Wainwright J (2018) Climate leviathan. A Political Theory of Our Planetary Future. Verso, London

Markard J, Raven R, Truffer B (2012) Sustainability transitions: an emerging field of research and its prospects. Res Policy 41:955-967

Markusson N, Ginn F, Singh Ghaleigh N, Scott V (2014) 'In case of emergency press here': framing geoengineering as a response to dangerous climate change. Wiley Interdiscip. Rev Clim Change 5: 281-290

Marx K (1867) Das Kapital: Kritik der politischen Oekonomie. Verlag von Otto Meissner, Hamburg

Matutinovic I (2007) An institutional approach to sustainability: historical interplay of worldviews, institutions and technology. J Econ Issues 41:1109-1137

McNeill JR (2001) Something new under the sun: an environmental history of the twentieth-century world. WW Norton \& Company, London

McNeill JR (2003) Observations on the nature and culture of environmental history. Hist Theory 42(4):5-43

McNeill JR, Engelke P (2014) The great acceleration: an environmental history of the Anthropocene since 1945. The Belknap Press of Harvard University Press, Cambridge and London

Meadows DH, Randers J, Behrens WW III (1972) The limits to growth: a report to the Club of Rome. Universe Books, New York

Melosi MV (2010) Humans, cities, and nature: how do cities fit in the material world? J Urban Hist 36:3-21

Merchant C (1981) The death of nature: women, ecology, and scientific revolution. Harper Collins, New York

Moore JW (2017) The Capitalocene, part I: on the nature and origins of our ecological crisis. J Peasant Stud 44:594-630

Moretti F, Pestre D (2015) Bankspeak. The language of world bank reports. New Left Rev 92:75-99

Morton T (2013) Hyperobjects. Philosophy and ecology after the end of the world. University of Minnesota Press, Minneapolis

Mosley S (2001) The chimney of the world: a history of smoke pollution in Victorian and Edwardian Manchester. White Horse Press, Cambridge

Norgaard KM (2011) Living in denial: climate change, emotions, and everyday life. MIT Press, Cambridge

Ophuls W (1977) Ecology and the politics of scarcity. WH Freeman, New York

Pinker S, Lakoff G (2007) Does language frame politics? PPR 14(1):59 71

Polk M (2014) Achieving the promise of transdisciplinarity: a critical exploration of the relationship between transdisciplinary research and societal problem solving. Sustain Sci 9:439-451

Purvis B, Mao Y, Robinson D (2019) Three pillars of sustainability: in search of conceptual origins. Sustain Sci 14(3):681-695

Robin L, Warde PC, Sörlin S (2018) The environment: a history of the idea. JHU Press

Robinson J (2004) Squaring the circle? Some thoughts on the idea of sustainable development. Ecol Econ 48:369-384
Rockström J, Steffen W, Noone K, Persson Å, Chapin FS III, Lambin E et al (2009) Planetary boundaries: exploring the safe operating space for humanity. Ecol Soc 14(2):32

Rosa EA, Machlis GE, Keating KM (1988) Energy and society. Annu Rev Sociol 14:149-172

Russill C, Nyssa Z (2009) The tipping point trend in climate change communication. Glob Environ Chang 19:336-344

Sardar Z (1993) Colonizing the future: the 'other' dimensions of future studies. Futures 25:179-187

Schneider B (2014) Red futures: the colour red in scientific imagery of climate change. In: Juneja M, Schenk GJ (eds) Disaster as image. Iconographies and Media Strategies across Europe and Asia. Schnell \& Steiner, Regensburg, pp 183-194

Scoones I, Newell P, Leach M (2015) The politics of green transformations. In: Scoones I, Newell P, Leach M (eds) The politics of green transformations. Pathways to sustainability. Earthscan, New York, pp 1-24

Scott JC (1998) Seeing like a state: how certain schemes to improve the human condition have failed. Yale University Press, New Haven

Shahar DC (2015) Rejecting eco-authoritarianism, again. Environ Values 24:345-366

Shearman DJ, Smith JW (2007) The climate change challenge and the failure of democracy. Greenwood Publishing Group, Westport

Steffen W, Broadgate W, Deutsch L, Gaffney O, Ludwig C (2015) The trajectory of the Anthropocene: the great acceleration. The Anthropocene Rev 2:81-98

Stirling A (2014) Emancipating transformations: from controlling "the transition" to culturing plural radical progress. Working Paper no 12, Geoengineering Governance Research. University of Oxford, University of Sussex and University College London, Oxford

Strunz S, Marselle M, Schröter M (2019) Leaving the "sustainability or collapse" narrative behind. Sustain Sci 14:1-12. https://doi.org/10. 1007/s11625-019-00673-0

Subcommission on Quaternary Stratigraphy (2015) Newsletter of the Anthropocene Working Group no 6. http://quaternary.stratigraphy. org/wp-content/uploads/2018/08/Anthropocene-Working-GroupNewsletter-Vol-6-release.pdf (accessed 26 June 2019)

Tollefson J (2017) Trump pulls United States out of Paris climate agreement. Nature News. https://www.nature.com/news/trump-pulls-united-statesout-of-paris-climate-agreement-1.22096 (accessed 20 June 2019)

Toulmin S, Goodfield J (1982) The discovery of time. University of Chicago Press, Chicago

United Nations (2015) Resolution adopted by the general assembly on 25 September 2015 70/1 transforming our world: the 2030 Agenda for Sustainable Development. United Nations, New York

Victor DG, Morgan MG, Apt J, Steinbruner J, Ricke K (2009) The geoengineering option. A last resort against global warming? Foreign Aff 88:64-76

Warde P (2018) The invention of sustainability: nature and Destiny, c. 1500-1870. Cambridge University Press, Cambridge

Warde P, Sörlin S, Robin L (2018) The environment: a history of the idea. John Hopkins University Press, Baltimore

White L (1967) The historical roots of our ecologic crisis. Science 155: 1203-1207

Wigley TM (2006) A combined mitigation/geoengineering approach to climate stabilization. Science 314(5798):452-454

Wilson S, Carlson A, Szeman I (2017) Petrocultures: oil, politics, culture. McGill-Queen's Press, Montreal

Yanarella EJ, Levine RS, Lancaster RW (2009) Green versus sustainability. Sustainability 2(5)

Zachos J, Pagani M, Sloan L, Thomas E, Billups K (2001) Trends, rhythms, and aberrations in global climate $65 \mathrm{Ma}$ to present. Science 292:686-693

Publisher's note Springer Nature remains neutral with regard to jurisdictional claims in published maps and institutional affiliations. 